\title{
Parameters for evaluation of clinical trial in mice infected with Trypanosoma cruzi
}

\author{
[Parâmetros para avaliação clínica de camundongos infectados pelo \\ Trypanosoma cruzi em experimentação] \\ G.J.S. Falkowski ${ }^{1}$, P.F. Sandri ${ }^{2}$, R. Tiyo ${ }^{1}$, D.L. Aleixo ${ }^{2}$, S.M. Araújo ${ }^{2}$ \\ ${ }^{1}$ Aluna de pós-graduação - Universidade Estadual de Maringá - Maringá, PR \\ ${ }^{2}$ Universidade Estadual de Maringá - Maringá, PR
}

\begin{abstract}
The effectiveness of clinical parameters in the evaluation of Trypanosoma cruzi infection was analyzed in male Swiss mice at 8 weeks old Animals were divided into HG (healthy) and IG (1400 trypomastigotes, intraperitoneally, Y strain - Trypanosoma cruzi). Quantitative and qualitative parameters were evaluated in non-consecutive days in the period, from $7^{\text {th }}-11^{\text {th }}$ and $15^{\text {th }}-18^{\text {th }}$ days of infection. There were significant differences $(\mathrm{P}<0.05)$ between both groups in both periods regarding water consumption, abdominal circumference and weight. The second group presented differences in amount of excreta, body temperature, move-up and mortality. There was no difference $(\mathrm{P}>0.05)$ between the groups in food consumption, exploration of self-cleaning and skin staining. The fecal feature differed between the groups in the second period. The occurrence of isolation was not practical. Differences were observed in the hair between groups, although the parameter had been interfered by fights between animals. The consumption of water, feed, excreta production, characteristic of the faeces, body temperature, abdominal circumference, move up, weight and mortality parameters are easy to be measured and effective in clinical differentiation of healthy mice infected with T. cruzi, elected in protocols for clinical study with mice, which is the first work to gather information of qualitative and quantitative clinical parameters evaluated in these animals.
\end{abstract}

Keywords: clinical analysis, Chagas disease, experimental infection, mice, Trypanosoma cruzi

\section{RESUMO}

Analisou-se a eficiência de parâmetros clínicos na avaliação da infecção pelo Trypanosoma cruzi em camundongos suiços, machos de 8 semanas. Os grupos foram divididos em GS (sadios) e GI (1400 tripomastigotas, intraperitoneal, cepa $Y$ - Trypanosoma cruzi). Avaliaram-se parâmetros quantitativos $e$ qualitativos em dias não consecutivos nos períodos, $7^{\circ}-11^{\circ}$ e $15^{\circ}-18^{\circ}$ dias de infecção. Observaram-se diferenças $(P<0.05)$ significativas entre os grupos, nos dois períodos: consumo de água, circunferência abdominal e peso; apenas no segundo período: quantidade de excretas, temperatura corporal, movimento-levantar e mortalidade. Não houve diferença $(P>0.05)$ entre os grupos: consumo de ração, exploração de auto-limpeza e coloração da pele. As fezes diferiram entre os grupos no segundo período. A ocorrência de isolamento não se mostrou prática. Diferenças no pêlo foram observadas entre os grupos, embora o parâmetro sofra interferência de brigas entre os animais. O consumo de água, ração, produção de excretas, característica das fezes, temperatura corporal, circunferência abdominal, movimento-levantar, peso e mortalidade são parâmetros fáceis de serem medidos e eficientes na diferenciação da clínica de camundongos sadios e infectados pelo T. cruzi, eleitos para protocolos de estudos clínicos com camundongos, sendo este o primeiro trabalho a reunir informações de parâmetros clínicos qualitativos e quantitativos avaliados nesses animais.

Palavras-chave: análise clínica, doença de Chagas, infecção experimental, Trypanosoma cruzi

Recebido em 18 de abril de 2011

Aceito em 19 de junho de 2012

E-mail: gisajanaina@hotmail.com 


\section{INTRODUCTION}

The use of model animals for studying infection is widespread throughout the world in several research fields and the quality of a model animal is linked to its ability to reproduce the parameters that allow a possible extrapolation of results to the human species (Chorilli et al., 2007). The experimental model of infection with Trypanosoma cruzi using non isogenic Swiss mice is very common and allows the study of a variety of parameters that are also observed in human infection (Araújo-Jorge et al., 2000). This model has a large number of published data which could contribute greatly to the growth and strength of experimental research which has to evaluate action mechanisms in new drugs, pathophysiological phenomena, among others.

From what was available for our search, we found there is no publication which deals with the relationship and quality assessment of clinical parameters and methodology for its measurement in mice infected with $T$. cruzi.

Thus, the purpose of this study is to list and provide methodology for measuring and evaluating quality parameters used to compare mice which are clinically healthy and infected by T. cruzi.

\section{MATERIALS AND METHODS}

Animals: A total of 34 Swiss, male, eight-weekold mice, purchased from the Central Vivarium of Universidade Estadual de Maringá (UEM) were divided in two experimental groups: Infected Group (IG) and Healthy Group (HG). Five animals in each group were sorted out for clinical evaluation. The groups were divided so that the average weight of mice from each group was statistically identical. The experiment was conducted as a blind controlled test, randomized by a raffle. The animals were assigned to conventional polypropylene cages with $30 \times 20 \times 13 \mathrm{~cm}$ dimensions, with a metal cap with partition systems for food and water (Model GC 111 - Beiramar®). The floor of the cage (bedding or bed) was covered by a layer of natural smectite (Cat Plus - Distributor Embramil), due to its high absorption capacity. The results shown are from one of three repetitions performed. The animals were kept in the Vivarium Sector of Parasitology's
Laboratory (UEM) where they remained for seven days for an adaptation period before starting the experiment, in an environment temperature of $22 \pm 1^{\circ} \mathrm{C}, 70 \%$ humidity and controlled light, with a light and dark cycle of 12 hours (Canadian..., 1993). Throughout the period, food and water were offered ad libitum. The pelleted (CR1 Nuvilab $®)$ feed was placed in a conventional feeder, located on the cage cover, taking care to not place broken pellets, preventing their loss. The water fountain was put in, fitted into the hole located on the cage cover. To prevent water leakage it was placed at maximum capacity and the entire fountains were replaced daily in order to avoid contamination by microorganisms.

After the adjustment period, the animals were inoculated with 1400 bloodstream trypomastigotes forms of $T$. cruzi, intraperitoneally. Parasitemia was determined by counting parasites daily, from the $4^{\text {th }}$ day of infection using the Brener technique (Brener, 1962). The parasitemia curve was determined by the average number of parasites in each animal per day.

The animals were evaluated regarding clinical parameters in five and four consecutive days, into two distinct periods, respectively: the 7 th and 11th days after infection, regarding parasitemia peak, and the 15th to the 18th day after infection (Silva and Nussenzweig, 1953), in a fixed schedule at 09:00 a.m. (Perez et al., 1995). Quantitative and qualitative parameters were evaluated. Among the quantitative parameters were weight $(\mathrm{g})$, water consumption (mL/animal) and food (g/animal), waste disposal (g/group) exploratory movements of selfcleaning and raise observed during $3 \mathrm{~min}$ (Eilam, 2003), temperature $\left({ }^{\circ} \mathrm{C}\right)$, abdominal circumference $(\mathrm{cm})$ and mortality $(\%)$. Weight parameter, food intake and excrete faeces with urine were evaluated by electronic weighing in a semi-analytical scale (BEL engineering - Class Mark II 500g). The measurement of the weight of excreta was done by weighing the lining of the cages after use, subtracted from the initial weight. The movement parameter was evaluated by observing the number of exploration movements (raise and self-cleaning) that each animal made during a three minute period. The temperature was measured in the anterior portion of the left thigh of the hind leg, using a 
digital infrared thermometer (Icel, TD-920.0387) expressed in centigrade degrees. Abdominal circumference was assessed with the aid of a wire measured by a ruler, expressed in millimeters. The mortality parameter was evaluated daily and expressed as a percentage of the cumulative period.

Among the qualitative parameters, the appearance of the faeces, hair and skin, eye color and occurrence of isolation were assessed. The evaluation was performed using numerically defined categories. The appearance of the faeces was categorized according to consistency in: 1 formed/pellets, 2 - pasty and 3 - diarrhea. The appearance of the hair parameter was evaluated as 1 - bristling and 2- not bristling. The appearance of the skin parameter was evaluated by observing the coloration of legs and tail: 1 pink, 2 - pale white and 3 - purple. The appearance of the eye parameter was evaluated according to color criteria: 1 - bright red and 2 opaque red. The occurrence of an isolation parameter was evaluated considering: 1 - no isolation and 2 - presence of isolation.

The data obtained through the analysis of clinical parameters was statistically compared (t student and comparison of proportions) using the Statistica 7.0 program with a $5 \%$ significance. The experimental protocol was approved by the Ethics Committee on Animal Experiments (ECAE) in the protocol number 030/2008.

\section{RESULTS AND DISCUSSION}

Figure 1 shows the parasitemia curve obtained for one of the three repetitions performed. The profile observed is typical for the Y strain of $T$. cruzi with a parasite peak on the eighth day of infection. This strain is highly virulent for the Swiss strain of mice, producing increased commitment of animal health, with mortality of all infected animals up 20 days after infection with the inoculum used.

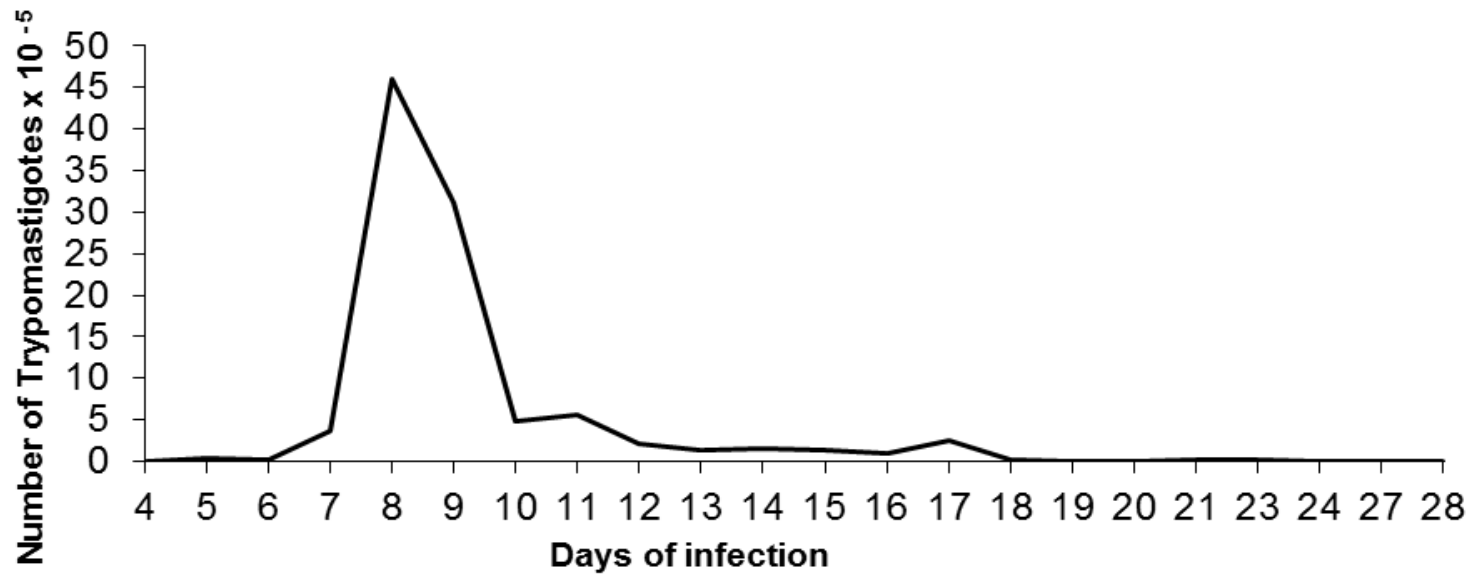

Figure 1. Mean parasitemia curve obtained in male, 8 week old, Swiss mice, infected with 1400 blood trypomastigotes of Y strain of Trypanosoma cruzi, intraperitoneally. Experimental data from one of three repetitions, with 5 animals per group.

In the analysis of quantitative parameters, significant differences were observed in both periods between the groups, regarding water consumption, abdominal circumference and weight (Table 1), showing that these are good parameters in the assessment of infected animals and healthy ones which were confirmed in repetition experiments. It is worth noting that 5 animals in each group were chosen by draw for clinical assessement. These results corroborate with ethical requirements to reduce the number of animals in the experimentation. Regarding water consumption, the healthy animals showed a higher and more homogeneous consumption over the two assessment periods, while the consumption by infected animals was extremely variable (Figure 2), according to the infection period, which reflects the state of health of each animal, expressed in the group consumption. As the average was calculated, this oscillation is certainly related to the variation in individual consumption of the animals, who become ill in 
different patterns during the observation period (Araújo and Chiari, 1996; Pupulim et al., 2010) (Figure 2). In a second moment, the measurement was done in a period of high morbidity, from when the animals attempt to initiate a reaction to infection (Silva and Nussensweig, 1953; Brener, 1962), which leads to the ingestion of a high volume of water (Richter and Brailey, 1929) (Figure 2).

Table 1. Clinical Significance of quantitative parameters evaluated and compared in Swiss male mice, 8 weeks old, healthy (HG) or infected with 1400 blood trypomastigotes of Y strain of T. cruzi according to the period. Experimental data from one of three repetitions, with 5 animals per group

\begin{tabular}{lcc}
\hline Parameter & Value p1 & Value p2 \\
\hline Weight & 0.0001 & 0.0001 \\
Water consumption & 0.0002 & 0.0262 \\
Feed consumption & 0.3641 & 0.6497 \\
Quantity excreta & 0.3414 & 0.0138 \\
Temperature & 0.2120 & 0.0399 \\
Abdominal circumference & 0.0006 & 0.0094 \\
Exploration / Raise & 0.4403 & 0.0179 \\
Exploration / Self-cleaning & 0.3542 & 0.3042 \\
Mortality & $*$ & 0.0325 \\
\hline
\end{tabular}
$\mathrm{P}<0.05$

$\mathrm{P} 1$ corresponds to the value of $\mathrm{p}$ in the first evaluation period $=7^{\text {th }}-8^{\text {th }}$ day of infection;

$\mathrm{P} 2$ corresponds to the value of $\mathrm{p}$ in the second evaluation period $=15^{\text {th }}-18^{\text {th }}$ day of infection;

*Zero for both groups.

Abdominal circumference proved to be a useful parameter in differentiating the compared groups (Table 1). With this parameter, the differentiation between HG and IG is easy because when the infection process is installed, mice become debilitated, cachectic, with generalized edema, regulated by the concentration of TNF-alpha and other immunological markers (Truyens et al., 1999). This is a good clinical parameter to analyze, but in order not to make any mistakes in the evaluation, generating data with excellence, the animal must be immobilized and the measurement performed in the same anatomical site, by a single experimenter, eliminating variations due to the size of the hand and the way the mice are manipulated, avoiding too much stretching and compression of the animal's skin (Verçosa Júnior et al., 2006).

The weight analysis was initially more homogeneous, but with the evolution of the acute phase of infection, the second evaluation period, there was a significant weight loss (Figure 2), which was already expected due to general debility caused by the infection with the Y strain $T$. cruzi, which provides increased morbidity culminating in a high mortality rate (Silva and Nussensweig, 1953). On the 17th day of infection, there was a false weight gain. This is because the data obtained was an average, however, the animals get sick and die differently. Thus, after the mortality of the weaker mice, there is an increase in the average weight, with a rise in the curve which does not represent clinical improvement, but the individuality of response to the infection, which was observed after the completion of several experiments (Queluz et al., 2002). In rebuttal, the individual data would provide a better visualization of the weight evolution, nevertheless, there is limited feasibility, due to the large number of samples used in experiments with mice (Ferreira et al., 2005). 

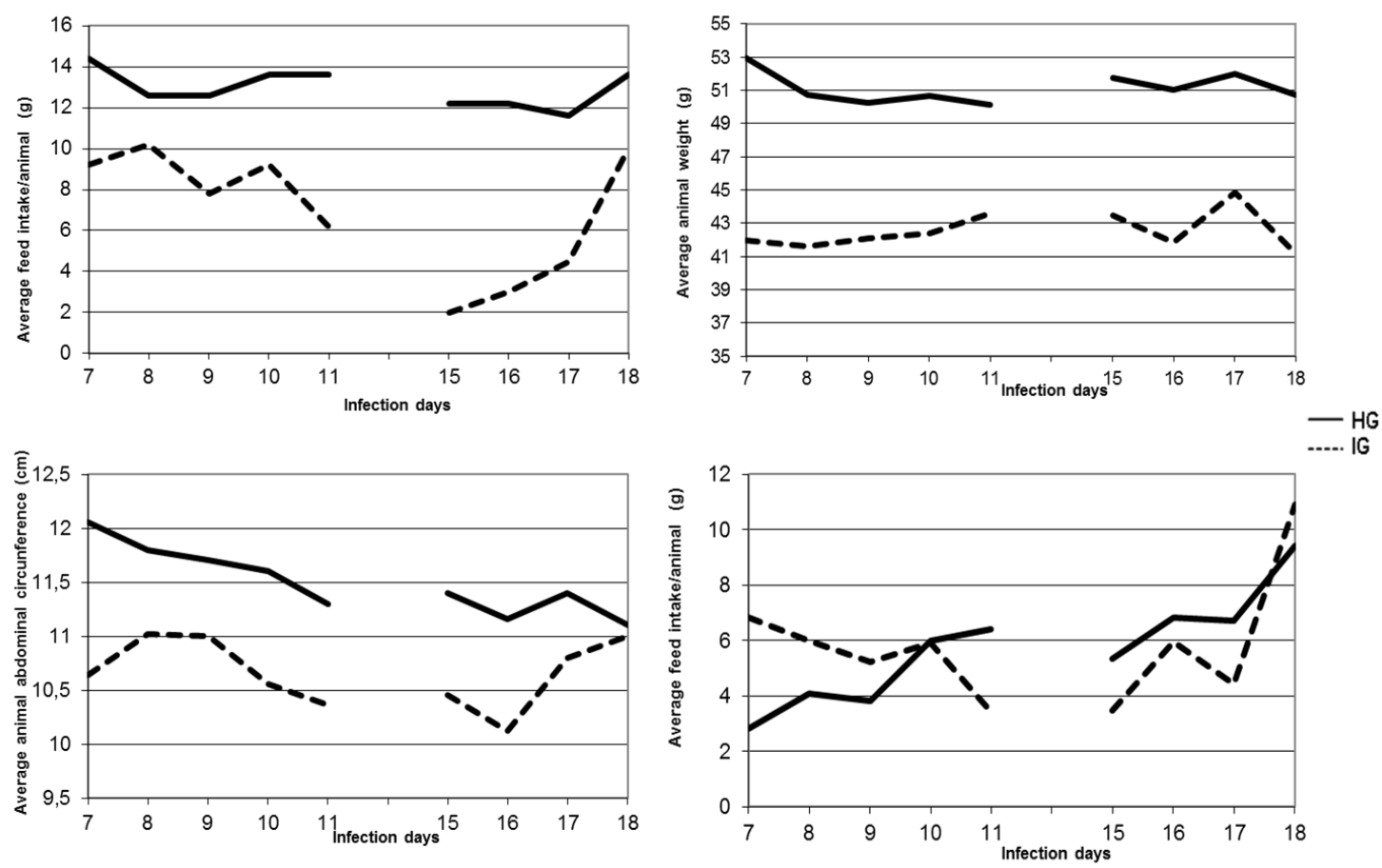

Figure 2. Analysis of clinical parameters of the mean volume of water intake, weight, abdominal circumference and feed intake in both periods. Experimental data from one of three repetitions, with 5 animals per group.

The evolution dynamics of feed intake were different between groups, but the difference between the values was not significant (Table 1). Other authors have found $\mathrm{p}$ values closer in significance for this parameter (Sandri, 2011) when compared to pharmacological interventions. This discussion is relevant since this parameter is very important in clinical evaluations. A strategy to improve the assessment of feed intake may be to increase the sample or use metabolic cages to assess the cost saving benefits of other strategies. While in the healthy group the average feed intake per animal has increased throughout the period, for the infected animals, there was initially a decrease in consumption with some rise during the second period (Figure 2). This result suggests again that the data analysis using the medium may be a bias in the experiment, due to the individual variation in feed consumption of animals that show different evolution of morbidity and mortality throughout the evaluated period of infection. Thus, the analysis of individual feed intake may be a more appropriate way of tackling this parameter (Selman et al., 2001).
Another point to be discussed is the need of a control group inoculated only with saline. Considering the evolution of weight, temperature, water or food intake and exploratory movements, it should be noted that data (not shown) from our laboratory show no significant difference compared to the normal group when intraperitoneal injection of saline was accomplished. This comparison, besides allowing us to decide to no longer include this group in our experimental routine, decreases the number of animals to be used and the researcher's work still leads us to note that being in experimentation is the most stressful factor for the animals. A single intraperitoneal inoculation with a small volume $(0.2 \mathrm{~mL})$, taking care in all the procedures involved, causes no significant change in clinical parameters evaluated.

The evaluation of self-cleaning exploratory movements had no significant difference in the two periods (Table 1). The parameter of exploratory movements to rise presented a significant difference between the healthy and ill animals only in the second period (Table 1). These results attest to the value of this parameter 
to measure bio-physio-pathogenic interventions in mice (Oliveira et al., 2008).

There are softwares for behavioral studies in mice which measure the parameters of exploratory movements (Drai et al., 2001). However, these programs are limited regarding the number of tests, and need to be constantly calibrated and refed (Machado et al., 2006). Moreover, their use can cause stress in animals by changing their behavior (Galsworthy et al., 2005) due to the emitted electrical signals. Thus, the method which remains the most effective is the visual assessment (Souza et al., 2006).

The evaluation of body temperature of animals showed a significant difference between the HG and IG groups only in the second study period (Table 1). This parameter is important, especially when dealing with infectious diseases, and may be related to the mortality of animals (Vlach, 2000). The measurement of body temperature can be achieved using the rectal thermometer
(Crawley et al., 1993). However, in the present study we used an infrared thermometer in order to minimize the stress suffered by animals (Warn et al., 2003) and make the clinical evaluation routine easier with groups that contain more animals whenever necessary. The stress reduction is an important factor because studies show it can cause physiological changes, influencing the results (Kant et al., 1991).

The faeces feature in the second period differed in the groups of infected and healthy animals (Table 2, Figure 2). The faeces of infected animals were less consistent, characterizing periods of diarrhea. This change could be expected in the infection by $T$. cruzi, due to neuronal depletion. Experimental infection of mice with $T$. cruzi reduces the number of neurons in the myenteric plexus which causes physiological and functional changes of the gastrointestinal tract, which changes the consistency of faeces (Moreira et al., 2011).

Table 2. The appearance of the faeces from healthy Swiss male mice, (HG) or infected (IG) with 1400 blood trypomastigotes of Y strain of $T$. cruzi according to the evaluation period. Experimental data from one of three repetitions, with 5 animals per group

\begin{tabular}{|c|c|c|c|c|c|c|c|c|c|c|c|c|}
\hline \multirow[b]{3}{*}{ Groups } & \multicolumn{6}{|c|}{ Appearance of the faeces $1^{\text {st }}$ period } & \multicolumn{6}{|c|}{ Appearance of the faeces $2^{\text {nd }}$ period } \\
\hline & \multicolumn{2}{|c|}{ Normal } & \multicolumn{2}{|c|}{ Inconsistent } & \multicolumn{2}{|c|}{ Diarrheal } & \multicolumn{2}{|c|}{ Normal } & \multicolumn{2}{|c|}{ Inconsistent } & \multicolumn{2}{|c|}{ Diarrheal } \\
\hline & $\mathrm{n}^{\circ}$. & $\%$ & $\mathrm{n}^{\circ}$. & $\%$ & $\mathrm{n}^{\mathrm{o}}$. & $\%$ & $\mathrm{n}^{\mathrm{o}}$. & $\%$ & $\mathrm{n}^{\circ}$. & $\%$ & $\mathrm{n}^{\mathrm{o}}$. & $\%$ \\
\hline HG & 5 & 100 & 0 & 0 & 0 & 0 & 4 & 80 & 1 & 20 & 0 & 0 \\
\hline IG & 1 & 20 & 3 & 60 & 1 & 20 & 0 & 0 & 3 & 60 & 2 & 40 \\
\hline
\end{tabular}

$* \mathrm{p}<0.05\left(\mathrm{p}_{1}{ }^{0}=0.3739 ; \mathrm{p}_{2}{ }^{0}=0.0432\right)$

The analysis of the occurrence of isolation was not feasible due to the need for a great period of time in its evaluation. One possible optimization to measure this parameter would be the use of a camcorder, not only during the vivarium light period, but also in the dark, since mice are rodents and have nocturnal habits (Pistori and Souza, 2010).

Another parameter that showed no statistically significant difference between HG and IG was the appearance of the hair. This result indicates that for the animals, apart from infection, being in the experimentation is in itself a stress factor. A difference was observed visually on the color and consistency of hair between the groups, however, when this qualitative parameter was quantified numerically in categories it was not possible to express this difference statistically. Although the appearance of the coat is a good parameter to assess diseases in mice, more time would be necessary to measure it due to external interference, especially in fights that occur between animals of the same group, which may change the health of the animal, complicating the assessment (Fox et al., 2007). The parameter color of skin, like paws and tail, was not feasible either, due to the fact that the infected mice die showing the same staining characteristics of healthy skin in mice, probably due to the short period between infection and mortality. Although the observation of significant anemia during the acute murine infection with $T$. cruzi (Ferraz, 2009) is described in literature, this fact was not reflected at all in changing the color of the skin during the study period. An analysis that could replace this with excellence in assessment would be the quantification of blood parameters related to anemia. The changes in eye color in mice can be studied in infections by other parasites such as 
Toxoplasma gondii (Couvreur and Thulliez, 1996). As in murine infection by T. cruzi, no important ocular change was observed. In our model this parameter did not present any changes.

Mortality was a good parameter to differ the HG from the IG (Tables 1 and 3). It is important to emphasize that besides the rate of cumulative mortality in the study period the evolution of morbidity can also be compared. Mortality is the greatest outcome of progressive morbidity expressed by different clinical parameters which can be studied. Mortality is very high in mice infected with the $\mathrm{Y}$ strain of $T$. cruzi, and any intervention which promotes the minimal decrease of this parameter should not pass unnoticed by a careful researcher.

Table 3. Mortality shown by healthy Swiss male mice (HG) or infected (IG) with 1400 blood trypomastigotes of $\mathrm{Y}$ strain of $T$. cruzi according to the day of infection. Experimental data from a repetition with 5 animals per group

\begin{tabular}{llllll} 
& \multicolumn{5}{c}{ Mortality (\%) according to the day of infection } \\
\cline { 2 - 6 } Groups & $7^{\text {th }}-11^{\text {th }}$ & $15^{\text {th }}$ & $16^{\text {th }}$ & $17^{\text {th }}$ & $18^{\text {th }}$ \\
\hline HG & 0 & 0 & 0 & 0 & 0 \\
IG & 0 & 20 & 20 & 60 & 80 \\
\hline
\end{tabular}

\section{CONCLUSIONS}

The consumption of water, feed, excreta production, characteristic of the faeces, body temperature, abdominal circumference, move up, weight and mortality parameters are easy to be measured and effective in clinical differentiation of healthy mice and those infected with $T$. cruzi.

\section{REFERENCES}

ARAÚJO, S.M.; CHIARI, E. Trypanosoma cruzi infection in offspring born to chagasic $\mathrm{C} 3 \mathrm{H} / \mathrm{He}$ mice mothers. Mem Inst Oswaldo Cruz., v.91, p.211-216, 1996.

ARAÚJO-JORGE, T.C. Modelos animais para o estudo in vivo da doença de Chagas e de seus aspectos histopatológicos: O camundongo. In: ARAÚJOJORGE, T.C e CASTRO (org.). Doença de Chagas: Manual para experimentação animal. Rio de Janeiro: Fiocruz, 2000. p.133-73.

BRENER, Z. Therapeutic activity and criterion of cure on mice experimentally infected with Trypanosoma cruzi. Rev. Inst. Med. Trop. São Paulo., v.4, p.389396, 1962.

CANADIAN council on animal care. Guide to the care and use of experimental animals. In: Olfert, E.D.; Cross, B.M.; McWilliam, A.A. Eds. Ottawa, Ontario:Laboratory Animal Care. 1993. cap.5, p.8289.

CHORILLI, M.; MICHELIN, D.C.; SALGADO, H.R.N. Animais de laboratório: O camundongo. Rev. Cienc. Farm. Básica Apl., v.28, p.11-23, 2007.
COUVREUR, J.; THULLIEZ, P. Acquired toxoplasmosis of ocular or neurologic site: 49 cases. Presse Med., v.25, p.438-442, 1996.

CRAWLEY, J.N.; CORWIN, R.L.; ROBINSON, J.K. et al. Anandamide, an endogenous ligand of the cannabinoid receptor, induces hypomotility and hypothermia in vivo in rodents. Pharmacol. Biochem. Behav., v.46, p.967-972, 1993.

DRAI, D.; KAFKAFI, N.; BENJAMINI, Y. et al. Rats and mice share common ethologically relevant parameters of exploratory behavior. Behavioural Brain Research., v.125, p.133-140, 2001.

EILAM, D. Open-field behavior withstands drastic changes in arena size. Behavioural Brain Research., v.142, p.53-62, 2003

FERRAZ, F.N. Efeito de bioterápicos sobre a infecção experimental em camundongos pelo Trypanosoma cruzi. 2009.52f. Dissertação (Mestrado em Biociências Aplicadas à Farmácia) - Universidade Estadual de Maringá, Maringá.

FERREIRA, L.M.; HOCHMAN, B.; BARBOSA, M.V.J. Modelos experimentais em pesquisa. Acta Cir. Bras., v.20, p.28-34, 2005.

FOX, J.G. BARTHOLD, S.W.; DAVISSON, M.T. The Mouse in Biomedical Research: Diseases. 2nd ed. San Diego: Elsevier, 2007. 75p.

GALSWORTHY, M.J.; AMREIN, I.; KUPTSOV, P.A. et al. A comparison of wild-caught wood mice and bank voles in the Intellicage: Assessing exploration, daily activity patterns and place learning paradigms. Behav. Brain Res., v.157, p.211-217, 2005. 
KANT, G.J.; BAUMAN, R.A.; PASTEL, R.H. et al. Effects of controllable vs. uncontrollable stress on circadian temperature rhythms. Physiol. Behav., v.49, p.625-630, 1991.

MACHADO, B.B.; DE ANDRADE, S.J.; GONÇALVES, W.N. et al. Topolino: Software livre para automatização do experimento do campo aberto. In: SEMINÁRIO DE COMPUTAÇÃO, 15., 2006, Blumenau. Anais... Blumenau: [s.n.] 2006. p.19-28.

MOREIRA, N.M.; SANT`ANA, D.M.G.; ARAÚJO, E.J.A. et al. Neuronal changes caused by Trypanosoma cruzi: an experimental model. An. Acad. Bras. Cienc., v.83, p.545-555, 2011.

OLIVEIRA, R.B.; NASCIMENTO, M.V.M.; VALADARES, M.C. et al. Avaliação dos efeitos depressores centrais do extrato etanólico das folhas de Synadenium umbellatum Pax. e de suas frações em camundongos albinos. Rev. Bras. Cienc. Farm., v.44, p.485-491, 2008 .

PEREZ, J.M.; LEBRAS, F.; FIDENNE, T. European Reference Method for in vivo Determination of Diet Digestibility in Rabbits. World Rabbit Sci., v.3, p.4143, 1995.

PISTORI, H.; SOUZA, K.P. Tecnologia adaptativa aplicada na biotecnologia: Estudos de caso e oportunidades. In: WORKSHOP DE TECNOLOGIA ADAPTATIVA. Escola Politécnica da USP, 4., 2010, São Paulo. Anais... São Paulo: [s.n.] 2010. p.16-21.

PUPULIM, A.R.T.; ARAUJO, S.M.; TOLEDO, M.J.O. et al. Canova medication modifies parasitological parameters in mice infected with Trypanosoma cruzi. Exp. Parasit., v.126, p.435-440, 2010.

QUELUZ, T.T.; SILVA, M.H.C.; ZANATTI, S.G. et al. Estudo do efeito da amiodarona sobre o peso corpóreo e sobre determinantes morfológicos e citopatológicos do pulmão em ratos machos e fêmeas das linhagens Wistar, Wistar-Kyoto e SHR. $J$. Pneumol., v.28, p.309-316, 2002.
RICHTER, C.; BRAILEY, M. Water intake and its relation to the surface area of the body. Proc. Natl. Acad. Sci. USA., v.15, p.570-578, 1929.

SANDRI, P.F. Efeitos do bioterápico 17DH na infecção pelo Trypanosoma cruzi em camundongos de diferentes idades. 2011. 70f. Dissertação (Mestrado em Biociências Aplicadas à Farmácia) - Universidade Estadual de Maringá, Maringá.

SELMAN, C.; LUMSDEN, S.; BUNGER, L. et al. Resting metabolic rate and morphology in mice (Mus musculus) selected for high and low food intake. $J$. Exp. Biol., v.204, p.777-784, 2001.

SILVA, L.H.P.; NUSSENZWEIG, V. Sobre uma cepa de Trypanossoma cruzi altamente virulenta para o camundongo albino. Fol. Clin. Boil., v.20, p.191-208, 1953.

SOUZA, M.M.; GARBELOTO, M.; DENEZ, K. et al. Avaliação dos efeitos centrais dos florais de Bach em camundongos através de modelos farmacológicos específicos. Rev. Bras. Farmacogn., v.16, p.365-371, 2006.

TRUYENS, C.; TORRICO, F.; LUCAS, R. et al. The endogenous balance of soluble tumor necrosis factor receptors and tumor necrosis factor modulates cachexia and mortality in mice acutely infected with Trypanosoma cruzi. Infect. Immun., v.67, p.55795586, 1999.

VERÇOSA JÚNIOR, D.; SOUZA-FAGUNDES, E.M.; CASSALI, G.D. et al. Efeito do miriadenolideo isolado de Alomia myriadenia (Asteraceae) sobre o tumor de Ehrlich ascítico no camundongo. Arq. Bras. Med. Vet. Zootec., v.58, p.788-798, 2006.

VLACH, K.D.; BOLES, J.W.; STILES, B.G. Telemetric evaluation of body temperature and physical activity as predictors of mortality in a murine model of staphylococcal enterotoxic shock. Comp Med., v.50, p.160-166, 2000.

WARN, P.A.; BRAMPTON, M.W.; SHARP, A. et al. Infrared body temperature measurement of mice as an early predictor of death in experimental fungal infections. Lab. Anim., v.37, p.126-131, 2003. 